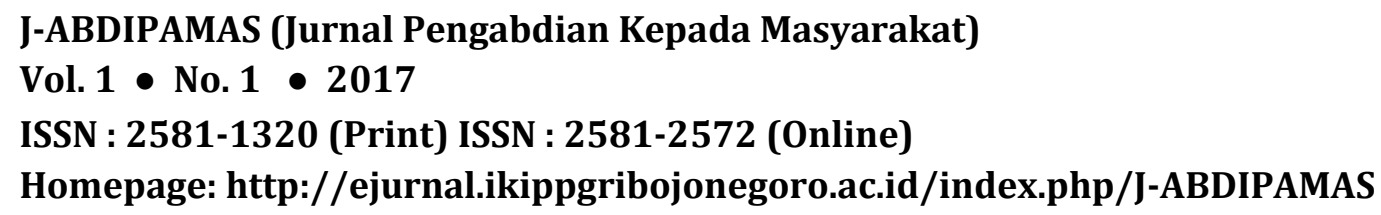

ISSN : 2581-1320 (Print) ISSN : 2581-2572 (Online)

Homepage: http://ejurnal.ikippgribojonegoro.ac.id/index.php/J-ABDIPAMAS

\title{
PEMBERDAYAAN REMAJA PANTI ASUHAN MELALUI PEMBUATAN NUGGET GUNA MENUMBUHKAN MINAT BERWIRAUSAHA
}

\author{
Monika Tiarawati $^{1} \&$ Widyastuti $^{2}$ \\ ${ }^{1}$ Universitas Negeri Surabaya. E-mail: monikatiarawati@unesa.ac.id \\ ${ }^{2}$ Universitas Negeri Surabaya. E-mail: widyastuti@unesa.ac.id
}

\begin{abstract}
Interest in entrepreneurship becomes very important for the current economic condition, because it has a positive impact for the long term is to make someone more financially independent through the development of creative ideas that can have selling points. Interest in entrepreneurship to be very need to be developed so it is necessary for teenagers orphanage have certain skills. One of the programs and activities that can be done is to equip the teenagers with skills and entrepreneurship skills through making nugget tahu and tempe. The results of these products can be sold to become a source of income. The implementation of training activities for the manufacture of nuget tahu and tempe was conducted at Mahbubiyah Orphanage, Surabaya, which was attended by 18 participants consisting of girls and orphanages. The training is held from $08.00-12.00$ WIB. The atmosphere during the training was quite conducive and interesting. Phase by stage the training was followed by the residents of the orphanage well and they were very enthusiastic about the training. The result of the questionnaire that has been filled by the participants shows that most of them feel happy and enjoy the atmosphere during the training of making nugget tahu and tempe. According to them the implementation of training activities making nugget tahu and tempe easy to follow, done and practiced on their own. In addition, the raw materials needed are also easy to obtain and the price is relatively affordable.
\end{abstract}

Keywords: Orphanage, young women, nuggets, training, entrepreneurial interests

\begin{abstract}
ABSTRAK
Minat berwirausaha menjadi hal yang sangat penting untuk kondisi perekonomian sekarang ini, karena memiliki dampak positif untuk jangka panjang yaitu menjadikan seseorang lebih mandiri secara finansial melalui pengembangan ide-ide kreatif yang dapat memiliki nilai jual. Minat berwirausaha menjadi sangat perlu dikembangkan sehingga perlu kiranya bagi remaja panti asuhan memiliki keterampilan tertentu. Salah satu program dan kegiatan yang dapat dilakukan adalah membekali para remaja tersebut dengan ketrampilan dan keahlian berwirausaha melalui pembuatan nugget tahu dan tempe. Hasil produk ini bisa dijual untuk menjadi sumber penghasilan. Pelaksanaan kegiatan pelatihan pembuatan nuget tahu dan tempe ini dilaksanakan di Panti Asuhan Mahbubiyah, Surabaya, yang diikuti oleh 18 peserta yang terdiri atas remaja putri dan pengurus panti asuhan. Pelatihan dilaksanakan mulai pukul 08.00 - 12.00 WIB. Suasana selama pelatihan cukup kondusif dan menarik. Tahap demi tahap pelatihan diikuti oleh para penghuni panti asuhan dengan baik dan mereka sangat antusias mengikuti pelatihan yang diberikan. Hasil angket yang telah diisi oleh peserta menunjukkan bahwa sebagian besar merasa senang dan sangat menikmati suasana selama pelatihan pembuatan nugget tahu dan tempe. Menurut mereka pelaksanaan kegiatan pelatihan pembuatan nugget tahu dan tempe mudah diikuti, dilakukan dan dipraktekkan sendiri. Selain itu bahan baku yang dibutuhkan juga mudah didapatkan dan harganya relatif terjangkau.
\end{abstract}

Kata Kunci: Panti asuhan, remaja putri, nugget, pelatihan, minat wirausaha 
Tiarawati, Pemberdayaan Remaja Panti....119

\section{PENDAHULUAN}

Panti asuhan merupakan salah satu lembaga perlindungan anak yang berfungsi untuk memberikan perlindungan terhadap hak-hak anak (pedoman perlindungan anak, 1999). Anak-anak yang tinggal di panti asuhan biasanya berasal dari keluarga yang kurang mampu dari segi ekonomi atau ditelantarkan oleh orang tua/keluarganya. Mereka terlantar karena para orang tua sibuk mencari nafkah untuk memenuhi kebutuhan hidup yang semakin lama semakin sulit untuk dipenuhi. Selain itu karena salah satu atau kedua orang tua mereka meninggal dan tidak ada sanak saudara yang bersedia merawat, maka mereka terpaksa tinggal di panti asuhan. Menurut Santoso (2005), anak-anak panti asuhan ini diasuh oleh pengasuh yang menggantikan peran orang tua mereka dalam mengasuh, menjaga, dan memberikan bimbingan kepada anakanak agar menjadi manusia dewasa yang berguna dan bertanggung jawab atas dirinya maupun terhadap masyarakat di kemudian hari.

Berdasarkan hasil penelitian dari Kementerian Sosial terhadap 37 panti asuhan di 6 provinsi, memberikan gambaran tentang kualitas pengasuhan dalam panti asuhan di Indonesia, bahwa panti asuhan lebih berfungsi sebagai lembaga penyedia akses pendidikan daripada sebagai lembaga alternatif terakhir pengasuhan anak yang tidak dapat diasuh oleh orang tua atau keluarganya, sebagian besar anak asuh yang tinggal di panti asuhan masih memiliki kedua orang tua dan dikirim ke panti asuhan dengan alasan utama untuk melanjutkan pendidikan, dikarenakan sebagai penyedia akses pendidikan sehingga anak asuh harus tinggal lama di panti asuhan sampai lulus SLTA dan harus menjalani pembinaan daripada pengasuhan yang seharusnya mereka terima dari orang tuanya.

Panti Asuhan Mahbubiyah bernaung pada Yayasan Mahbubiyah Surabaya yang berdiri secara resmi dan disahkan dihadapan Notaris Ny. Endang Ifiati, SH pada tanggal 13 Maret 1999, di Surabaya dengan akte No. 4 tanggal 13 Maret 1999, kemudian diperbarui dengan Akta Notaris Ny. Inge, SH, M.Kn No, 02 tanggal 12 April 2010.

Program-program kegiatan yang dilaksanakan Yayasan Mahbubiyah terdiri dari 3 (tiga) program amal usaha, yaitu: (1) Panti Asuhan, (2) Taman Pendidikan Al-Quran (TPA/TKA), dan (3) Usaha Mandiri dan Koperasi. Adapun Sumber dana yang diperoleh guna mencukupi biaya operasional panti Asuhan berasal dari patra donatur panti asuhan Mahbubiyah, bantuan/sumbangan dari pemerintah, badan-badan usaha negeri atau swasta, perorangan, Kotak Infaq dan kegiatan usaha Panti Asuhan.

Para penghuni panti asuhan terdiri dari berbagai usia, pendidikan, serta latar belakang yang membuat mereka terpaksa tinggal di panti asuhan. Secara garis besar, yang menghuni panti asuhan Mahbubiyah minimal berusia 6 tahun, dengan pendidikan sekolah dasar, dan yang melatar belakangi mereka tinggal di panti asuhan adalah ketidaksiapan orang tua anak-anak panti secara ekonomi untuk memenuhi kebutuhan hidup sehari-hari serta untuk membiayai pendidikan mereka.

Panti asuhan Mahbubiyah menampung anak-anak asuh dari usia 6 tahun sampai usia 20 tahun. Anak-anak yang tinggal di panti asuhan Mahbubiyah berasal dari berbagai daerah. Bahkan terdapat beberapa penghuni panti yang tempat tinggalnya tidak jauh dari panti asuhan Mahbubiyah. Penghuni panti yang tinggal di sekitar panti asuhan Mahbubiyah dapat melakukan kegiatan rutinitas seperti biasanya, dan untuk kegiatan di panti yang harus diikuti misalnya mengaji, belajar bersama dengan penghuni panti yang lain. Setelahnya mereka dapat kembali ke rumah mereka masing-masing.

Meskipun tinggal di panti asuhan, mereka juga bersekolah seperti anak-anak seusia mereka pada umumnya. Biaya sekolah biasanya diperoleh dari bantuan para donatur yang dikelola oleh pengurus panti asuhan. Di panti asuhan Mahbubiyah 
terdapat beberapa donatur tetap yang siap membantu untuk keperluan pengelolaan panti. Di sisi lain, para penghuni panti juga diajarkan untuk tidak selamanya bergantung kepada panti asuhan Mahbubiyah. Sehingga para penghuni panti perlu untuk mendapatkan pembekalan soft skill yang nantinya dapat digunakan untuk menambah penghasilan. Dengan kata lain para penghuni panti tidak akan selamanya tinggal di panti. Sehingga mereka perlu memiliki keterampilan yang dapat dikembangkan ketika mereka keluar dari panti asuhan. Selain itu agar kehidupan para anak asuh di panti asuhan tidak selalu tergantung pada orang lain, maka anak asuh yang berada di usia produktif hendaknya mempunyai sifat kemandirian melalui wirausaha. Melalui wirausaha, setidaknya mereka dapat memenuhi kebutuhan mereka sendiri ketika di panti dan ketika mereka menjadi dewasa, mereka akan menjadi manusia yang berguna bagi masyarakat dengan membuka lapangan kerja baru bagi lingkungannya karena saat ini pengangguran di Indonesia semakin hari semakin meningkat jumlahnya seiring dengan berjalannya waktu. Menjadi seorang wirausaha merupakan salah satu pendukung yang menentukan maju mundurnya perekonomian, karena bidang wirausaha mempunyai kebebasan untuk berkarya dan mandiri. Wirausaha inilah yang mampu menyerap tenaga kerja dengan menciptakan lapangan kerja yang baru sesuai dengan bidang yang ditekuni.

Jumlah pengangguran di Indonesia semakin hari semakin meningkat jumlahnya. Hampir sebagian besar pengangguran tersebut adalah pengangguran terdidik (sarjana). Hal tersebut dikarenakan pola pikir mereka yang masih berusaha mencari pekerjaan (job seeker) dibanding dengan menciptakan lapangan pekerjaan (job creator). Salah satu usaha untuk mengubah pola pikir itu adalah dengan menumbuhkan jiwa wirausaha. Dengan wirausaha ini diharapkan mampu melatih kemandirian dan menciptakan lapangan kerja baru.

Menumbuhkan jiwa wirausaha dengan membekali keterampilan yang berguna sangat diperlukan oleh masyarakat khususnya masyarakat yang belum memiliki pekerjaan (pengangguran). Pengangguran banyak sekali dijumpai di masyarakat perkotaan maupun pinggiran dan sebagian besar mereka adalah kaum remaja putus sekolah. Mereka tidak memiliki ketrampilan khusus yang dapat mendukung untuk mencari kerja. Kondisi inilah yang sangat dikuatirkan oleh lembaga sosial yang banyak menampung anak-anak maupun remaja yang bermasalah sosial yaitu panti asuhan. Panti asuhan merupakan salah satu tempat untuk menampung anak-anak, remaja, maupun dewasa yang kurang beruntung dalam permasalahan sosial (Muchti, 2000).

Untuk berwirausaha, anak-anak asuh yang tinggal di panti asuhan harus mempunyai keterampilan-keterampilan tertentu. Melalui keterampilan yang mereka miliki, para anak asuh dapat melakukan kreativitas dan bersikap produktif. Upaya untuk meningkatkan kualitas sumber daya manusia yang ada di panti asuhan dapat dilakukan dengan melakukan pelatihan yang dapat mengasah kemampuan soft skill maupun hard skill. Di panti asuhan Mahbubiyah, para penghuni panti beberapa kali mendapatkan pelatihan kewirausahaan, yang tujuannya untuk melatih dan mengembangkan bakat kewirausahaan, sehingga diharapkan mereka dapat lebih mandiri secara finansial. Bentuk pelatihan yang sudah pernah diterima oleh penghuni panti asuhan diantaranya adalah membuat kerudung lukis, menjahit kerudung dengan teknik unfinish. Para penghuni panti asuhan Mahbubiyah mengharapkan akan lebih banyak mendapatkan pelatihan yang lain dan yang lebih mudah dipraktekkan sendiri. Pelatihan adalah pengajaran atau pemberian pengalaman kepada seseorang untuk mengembangkan tingkah laku (pengetahuan, skill, sikap) agar mencapai sesuatu yang diinginkan (Marzuki, 2010: 174). Dengan mendapatkan pelatihan pengembangan bakat, dapat 
menjadi sarana bagi penghuni panti untuk mengasah soft skill mereka. Pelatihan yang diajarkan tidak hanya sekedar untuk mengembangkan bakat maupun mengasah soft skill saja, akan tetapi dapat digunakan untuk menambah uang saku, dan mereka akan menjadi lebih mandiri secara finansial.

\section{Rumusan Masalah}

Berdasarkan hasil wawancara dengan Ketua Panti Asuhan Mahbubiyah serta beberapa penghuni panti asuhan diketahui bahwa permasalahan utama yang dihadapi oleh penghuni panti asuhan Mahbubiyah adalah kurangnya pelatihan maupun pengembangan bakat bagi penghuni panti, yang diharapkan mampu meningkatkan kreatifitas dan produktivitas. Padahal dengan soft skill dan kreatifitas akan menjadikan mereka lebih mandiri secara finansial, dan mereka akan mampu memenuhi kebutuhan hidupnya dari hasil usaha nya sendiri. Untuk kedepannya mereka dapat mengembangkan keterampilan yang telah diajarkan ketika mereka masih menghuni panti asuhan. Sehingga mereka tidak selamanya bergantung kepada orang lain.

\section{Tujuan Kegiatan}

Kegiatan pelatihan yang diajarkan kepada para penghuni panti asuhan Mahbubiyah bertujuan untuk mendorong mereka lebih mandiri dan memberikan bekal ketrampilan yang dapat digunakan bagi penghuni panti di masa yang akan datang. Dengan memiliki bekal keterampilan dasar yang memadai, para penghuni panti dapat mengembangkan ide-ide kreatif sehingga dapat menghasilkan produk yang memiliki nilai jual. Ketika tidak lagi tinggal di panti, mereka akan lebih siap dan lebih mandiri.

Saat ini anak asuh yang dimiliki Panti Asuhan Mahbubiyah terbagi berdasarkan gender, tempat tinggal, serta tingkat pendidikan. Secara lengkap, jumlah keseluruhan anak asuh di panti asuhan Mahbubiyah seperti yang tercantum pada tabel di bawah ini.

Tabel 1. Rincian Daftar Anak Asuh Panti Asuhan Mahbubiyah

\begin{tabular}{|c|c|}
\hline KRITERIA & JUMLAH \\
\hline \multicolumn{2}{|l|}{ Gender : } \\
\hline - $\quad$ Laki-laki & 19 \\
\hline - Perempuan & 11 \\
\hline \multicolumn{2}{|l|}{ Tempat Mukim: } \\
\hline - Asrama & 26 \\
\hline - Non Asrama & 4 \\
\hline \multicolumn{2}{|l|}{ Tingkat Pendidikan: } \\
\hline - $\quad$ PAUD /TK & 1 \\
\hline - $\mathrm{SD} / \mathrm{MI}$ & 11 \\
\hline - $\quad$ SMP/MTs & 7 \\
\hline - SMA/SMK/MAN & 11 \\
\hline TOTAL & 30 \\
\hline
\end{tabular}

Berdasarkan data pada tabel di atas, dapat diketahui bahwa jumlah penghuni panti asuhan Mahbubiyah secara keseluruhan sebanyak 30 orang dan sebagian besar anak asuh pada panti asuhan tersebut berada pada usia remaja. Usia remaja merupakan usia produktif dimana pada masa tersebut mereka diharapkan mampu mengisi waktunya dengan hal-hal yang positif serta melakukan kegiatan-kegiatan yang dapat menambah pengetahuan dan keterampilan mereka. Produktivitas remaja perlu diimbangi dengan ide-ide kreatif dan inovatif. Ide kreatif dan inovatif dapat menjadi sarana bagi remaja, dalam hal ini para penghuni panti untuk mengembangkan bakat mereka untuk lebih mandiri. Kemandirian yang diharapkan di kemudian hari, para 
penghuni panti dapat lebih produktif dengan membuat karya yang kreatif dan memiliki nilai jual. Sehingga kemandirian secara finansial dapat mereka rasakan, bahkan mereka dapat menyerap tenaga kerja lain.

\section{Kewirausahaan}

Peranan kewirausahaan dalam pengembangan ekonomi bukan sekedar mencakup upaya peningkatan output dan pendapatan per kapita, tetapi meliputi upaya menimbulkan perubahan pada struktur bisnis dan masyarakat. Kewirausahaan sangat berkaitan dengan perubahan, dimana menurut Schumpeter menyatakan sebagai kekuatan "Destruksi kreatif" yang cenderung meniadakan cara-cara baku untuk bertindak, dengan menciptakan cara-cara baru untuk melaksanakan aneka macam pekerjaan serta tugas-tugas.

Pembekalan keterampilan berwirausaha menjadi salah satu program pemerintah, baik jangka panjang maupun jangka pendek guna memperkecil jumlah keluarga miskin karena tidak memiliki pekerjaan atau pengangguran yang tidak berpenghasilan. Program pemerintah tersebut untuk mensiasati jumlah pengangguran dan kemiskinan yang mengalami peningkatan. Pengangguran dan kemiskinan terjadi karena perbandingan antara jumlah penawaran kesempatan kerja di seluruh sektor, baik di dalam maupun di luar negeri yang meliputi sektor industri, pertanian, pertambangan, transportasi, pariwisata, dan lain-lain tidak sebanding jumlah lulusan atau penawaran tenaga kerja baru.

Dalam kewirausahaan, pemilik bisnis harus bertindak cukup berani dalam mencoba ide baru mereka, cukup fleksibel untuk mengesampingkan ide yang tidak sukses, dan cukup bijaksana untuk belajar mengenai apa yang akan sukses berdasarkan observasi mereka terhadap ide yang tidak sukses. Dalam menjalankan kewirausahaan, pemilik bisnis harus pula berani menanggung resiko atas ketidakpastian dalam menjalankan usaha/bisnis. Unsur ketidakpastian ini disebabkan faktor-faktor eksternal yang tidak dapat diprediksi oleh pelaku usaha.

Pada Era Globalisasi, di saat dunia semakin transparan, akan tampak ketatnya persaingan bisnis perusahaan nasional, perang ekonomi lewat perdagangan antarbangsa yang berebut menguasai pasar dunia dalam bidang barang dan jasa. Dampak lain kaitan antara kewirausahaan dan perubahan adalah peranan yang dimainkan oleh para entrepreneur dalam memajukan teknologi-teknologi inovatif, produk-produk dan servis-servis baru. Berbagai peran yang dimainkan oleh para pelaku usaha tersebut secara langsung akan berdampak pada peningkatan penyerapan jumlah tenaga kerja, sehingga dapat mengurangi tingkat pengangguran.

Perkembangan wirausaha di Indonesia masih sangat terbatas, bahkan jauh tertinggal dibandingkan dibandingkan negara tetangga seperti Malaysia, Thailand dan Singapura. Dikawasan Negara-negara di kawasan Asia Pasifik, jumlah wirausaha Indonesia juga terbilang rendah. Rasio kewirausahaan dibandingkan penduduk di Indonesia hanya 1:83 sedangkan di Filipina 1:66, Jepang 1:25 bahkan Korea kurang dari 20. Berdasarkan rasio secara Internasional, rasio unit usaha ideal adalah 1:20. (Yuyus Suryana, Kartib Bayu, 2011:14-15).

Dalam rangka menumbuhkan minat wirausaha, Bank Indonesia (BI) menyelenggarakan Entrepreneurship Strategic Policy Forum dengan obyek sasarannya adalah mahasiswa. Alasan mahasiswa yang menjadi obyek sasaran, agar kedepannya mahasiswa dapat menjadi pilot project kaum muda bagi masyarakat yang berminat untuk wirausaha. Selanjutnya langkah yang dilakukan oleh BI ini untuk mendorong peranan wirausaha dalam perekonomian Indonesia. 
Suryana (2003:1) mengungkapkan bahwa kewirausahaan adalah kemampuan kreatif dan inovatif yang dijadikan dasar, kiat, dan sumber daya untuk mencari peluang menuju sukses. Jadi, dapat disimpulkan bahwa kewirausahaan adalah kemampuan untuk menciptakan sesuatu yang baru dan berbeda melalui berpikir kreatif dan bertindak inovatif untuk menciptakan peluang. Kreativitas dan inovasi menjadi suatu tuntutan bagi pelaku usaha agar kesempatan dan peluang dapat ditangkap dengan baik oleh wirausahawan.

Menurut Bygrave dalam Saiman (2009:74), terdapat tiga komponen utama yang sebaiknya dilakukan dan dievaluasi bagi seseorang yang ingin sukses untuk membuka usaha, yaitu:

1. The opportunity - kesempatan. Apakah dengan adanya suatu kesempatan kita akan mampu menangkap dan menjalankannya di kemudian hari.

2. The entrepreneur (and the management team) - entrepreneur dan tim manajemen. Apakah kita mampu menjadi wirausahawan dengan membentuk suatu tim manajemen yang solid.

3. The resources needed to start the company and make it grow - kebutuhan berbagai sumber daya untuk memulai usaha dan pertumbuhan perusahaan. Apakah berbagai sumber daya yang mungkin kita perlukan mampu kita sediakan, minimal sumber bahan baku, sumber daya manusia, sumber daya modal. Jika memungkinkan dapat menguasai faktor produksi utama/6M (men, money, material, machine, method, market) ditambah dengan sumber daya tanah dan manajemen.

\section{Nugget Tahu dan Nugget Tempe}

Nugget tahu merupakan kreasi makanan yang dapat diolah sendiri (handmade) yang bahan dasarnya mayoritas adalah tahu. Kreasi dalam membuat nugget tahu dapat digabungkan dengan bahan lain seperti sayur dan daging ayam. Nugget merupakan salah satu bentuk produk makanan beku siap saji, yaitu produk yang telah mengalami pemanasan sampai setengah matang (precooked), kemudian dibekukan (Afrisanti, 2010). Produk beku siap saji ini hanya memerlukan waktu penggorengan selama 1 menit pada suhu $150^{\circ}$ C. Tekstur nugget tergantung dari bahan asal yang digunakan (Astawan, 2007).

Nugget adalah suatu bentuk produk olahan daging yang terbuat dari daging giling yang dicetak dalam bentuk potongan empat persegi dan dilapisi dengan tepung berbumbu (battered dan braded) (Maghfiroh,2000). Nugget dikonsumsi setelah melalui proses penggorengan rendam (deep fat frying) (Saleh et al, 2002). Nugget dibuat dari daging giling yang diberi bumbu, dicampur bahan pengikat, kemudian dicetak dengan bentuk tertentu, dikukus, dipotong dan dilumuri perekat tepung (batter) dan diselimuti tepung roti (breading). Nugget digoreng setengah matang dan dibekukan untuk mempertahankan mutunya selama penyimpanan.

\section{METODE PELAKSANAAN KEGIATAN}

Berdasarkan pada permasalahan yang telah dikemukakan oleh beberapa penghuni panti asuhan Mahbubiyah, maka dalam pelatihan pembuatan nugget tahu dan nugget tempe, yang menjadi pesertanya adalah remaja yang merupakan penghuni panti asuhan Mahbubiyah. Dalam pelatihan ini tidak dibedakan berdasarkan gender, mengingat remaja laki-laki pun sebenarnya juga membutuhkan pelatihan ini. Bahkan remaja laki-laki sangat antusias dalam mengikuti pelatihan pembuatan nuget tahu dan nuget tempe. Yang paling penting dalam pelatihan ini adalah cara menumbuhkembangkan minat berwirausaha dan mengembangkan bakat melalui ide- 
ide kreatif dan inovatif untuk dapat menangkap peluang serta kesempatan, khususnya bagi penghuni panti asuhan.

\section{Lokasi Kegiatan}

Kegiatan pengabdian kepada masyarakat (PKM) dilakukan bertempat di Panti Asuhan Mahbubiyah, Jalan Bentul I No. 6 Surabaya. Lokasi panti asuhan Mahbubiyah berada di kawasan pemukiman yang cukup padat penduduknya. Kegiatan pengabdian kepada masyarakat ini dilakukan dalam bentuk Workshop dan pelatihan olahan tahu dan tempe menjadi bentuk nugget tahu dan nugget tempe yang ditujukan untuk para remaja yang tinggal dalam panti asuhan. Adapun data jumlah peserta pelatihan secara keseluruhan berjumlah 18 orang yang terdiri dari remaja baik laki-laki maupun perempuan. Pelatihan pembuatan nugget tahu dan nugget tempe ini dimulai pada pukul 8 pagi dan berakhir pada pukul 3 sore.

Di awal pelatihan diberikan penjelasan oleh narasumber tentang pembuatan nugget tahu dan nugget tempe oleh tim pelaksana penelitian PKM dan dilanjutkan dengan pemberian pemahaman singkat tentang motivasi berwirausaha kepada para remaja.

Pada akhir kegiatan pelatihan dibagikan sejumlah angket yang harus diisi oleh para peserta pelatihan. Tujuan diberikan angket tersebut adalah untuk mengetahui seberapa besar respon peserta program pelatihan yang diberikan, termasuk materi pelatihan, dampak pelatihan terhadap masa depan peserta.

\section{HASIL DAN PEMBAHASAN}

Salah satu usaha untuk mengantisipasi timbulnya pengangguran akibat putus sekolah atau kesulitan mencari pekerjaan di panti asuhan adalah dengan menciptakan suatu usaha mandiri melalui usaha pembuatan produk nugget. Produk nugget tahu dan nugget tempe merupakan produk hasil olahan makanan beku siap saji yang terbuat dari tahu dan tempe. Produk nugget ini sangat praktis dan sederhana dalam pengolahannya namun memiliki nilai gizi yang tinggi. Bahan baku produk ini juga mudah diperoleh dan murah, sehingga siapapun dapat mengolahnya sendiri. Dengan alasan pertimbangan tersebut peneliti tertarik untuk memilih produk nugget tahu dan nugget tempe sebagai produk hasil olahan yang diajarkan kepada remaja putri di panti asuhan Mahbubiyah.

Berdasarkan hasil angket kegiatan pelatihan diketahui bahwa sebagian besar peserta berpendapat bahwa kegiatan pelatihan ini mudah dilakukan dan mudah diingat. Mereka juga mampu mengikuti proses kegiatan pelatihan pembuatan nugget tahu dan nugget tempe dari awal hingga akhir proses pembuatan nugget, sehingga ketika kegiatan pelatihan ini berakhir maka peserta mampu untuk membuat produk nugget tahu dan nugget tempe sendiri. Disamping itu, selama mengikuti pelatihan mereka merasa senang dan nyaman, dengan perasaan senang ini menstimuli intensi mereka untuk berwirausaha khususnya produk nugget tempe dan nugget tahu. Meskipun produk nugget ini sangat sederhana dan mudah dilakukan, namun jika produk nugget ini dikemas dengan desain yang eklusif maka dapat menambah nilai jual yang tinggi.

Kegiatan pelatihan ini mampu memotivasi intensi anak-anak panti asuhan untuk berwirausaha melalui pelatihan pembuatan nugget tahu dan nugget tempe. Pembinaan dan pelatihan keterampilan membuat nugget ini bertujuan sebagai bekal para remaja khususnya remaja untuk menumbuhkan jiwa kewirausahaan sekaligus dapat membantu meningkatkan kesejahteraan hidup melalui pemberdayaan ekonomi baik di lingkup panti asuhan maupun masyarakat luas. 


\section{Pembahasan Respon Peserta Selama Mengikuti Kegiatan Pelatihan}

Berdasarkan hasil angket kegiatan pelatihan diketahui bahwa sebagian besar peserta merespon kegiatan ini dengan baik. Jawaban peserta rata-rata setuju dan sangat setuju. Namun begitu, untuk variabel minat berwirausaha pada angket beberapa jawaban peserta pelatihan menunjukkan rata-rata jawaban antara cukup setuju dan setuju, yang berarti bahwa minat berwirausaha pada peserta masih perlu ditumbuhkan lagi. Hal ini perlu dimaklumi karena masih ada sebagian peserta yang masih duduk di bangku Sekolah Dasar (SD) sehingga bisa saja mereka masih belum mempunyai gambaran tentang makna berwirausaha. Selain itu respon dari variabel minat berwirausaha dengan kategori jawaban cukup, bisa juga disebabkan karena pada panti asuhan Mahbubiyah ini masih sangat minim diadakan pelatihan-pelatihan keterampilan kepada para penghuni panti. Pelatihan yang sebelumnya pernah diadakan di panti asuhan adalah membuat kerudung lukis serta membuat kerudung dengan teknik menyulam unfinish. Sedangkan pelatihan memasak baru pertama kali diberikan yaitu keterampilan membuat nugget dari bahan tahu dan tempe. Dengan mempertimbangkan bahwa keterampilan memasak membuat nugget tahu dan nugget tempe baru pertama kali diberikan, sehingga masih sangat sulit jika dalam waktu singkat langsung bisa menumbuhkan jiwa kewirausahaan.

Tabel 2. Respon Para Remaja Putri terhadap Pelatihan Pembuatan Nugget Tahu dan Tempe

\begin{tabular}{|c|c|c|c|c|c|c|}
\hline PERNYATAAN & $\begin{array}{l}\text { Sangat } \\
\text { tidak } \\
\text { setuju }\end{array}$ & $\begin{array}{l}\text { Tidak } \\
\text { setuju }\end{array}$ & $\begin{array}{c}\text { Cuk } \\
\text { up } \\
\text { setu } \\
\text { ju }\end{array}$ & setuju & $\begin{array}{c}\text { Sang } \\
\text { at } \\
\text { setuj } \\
\text { u }\end{array}$ & $\begin{array}{l}\text { Rata } \\
\text {-rata }\end{array}$ \\
\hline & $\%$ & $\%$ & $\%$ & $\%$ & $\%$ & \\
\hline $\begin{array}{l}\text { Pemateri/pelatih telah menjelaskan materi } \\
\text { dengan baik }\end{array}$ & $.0 \%$ & $.0 \%$ & $.0 \%$ & $66.7 \%$ & $\begin{array}{c}33.3 \\
\%\end{array}$ & 4.33 \\
\hline $\begin{array}{l}\text { Pemateri/pelatih telah menjelaskan secara } \\
\text { detail bagaimana cara memilih alat dan bahan } \\
\text { yang tepat untuk membuat nugget }\end{array}$ & $.0 \%$ & $.0 \%$ & $\begin{array}{c}11.1 \\
\%\end{array}$ & $55.6 \%$ & $\begin{array}{c}33.3 \\
\%\end{array}$ & 4.22 \\
\hline $\begin{array}{l}\text { Pemateri/pelatih mampu menjawab } \\
\text { pertanyaan dengan baik }\end{array}$ & $.0 \%$ & $.0 \%$ & $\begin{array}{l}5.6 \\
\%\end{array}$ & $61.1 \%$ & $\begin{array}{c}33.3 \\
\%\end{array}$ & 4.28 \\
\hline $\begin{array}{l}\text { Tim Pelaksana PKM dengan sabar } \\
\text { mendampingi para peserta sampai selesai } \\
\text { pelatihan }\end{array}$ & $.0 \%$ & $.0 \%$ & $\begin{array}{c}16.7 \\
\%\end{array}$ & $33.3 \%$ & $\begin{array}{c}50.0 \\
\%\end{array}$ & 4.33 \\
\hline $\begin{array}{l}\text { Saya mampu mengikuti proses pembuatan } \\
\text { nugget }\end{array}$ & $.0 \%$ & $5.6 \%$ & $\begin{array}{c}33.3 \\
\%\end{array}$ & $22.2 \%$ & $\begin{array}{c}38.9 \\
\%\end{array}$ & 3.94 \\
\hline $\begin{array}{l}\text { Saya merasa senang dan nyaman mengikuti } \\
\text { pelatihan pembuatan nugget }\end{array}$ & $.0 \%$ & $.0 \%$ & $\begin{array}{c}27.8 \\
\%\end{array}$ & $16.7 \%$ & $\begin{array}{c}55.6 \\
\%\end{array}$ & 4.28 \\
\hline $\begin{array}{l}\text { Kegiatan pelatihan ini merupakan kegiatan } \\
\text { yang tepat untuk melatih kemandirian }\end{array}$ & $.0 \%$ & $5.6 \%$ & $\begin{array}{c}22.2 \\
\%\end{array}$ & $27.8 \%$ & $\begin{array}{c}44.4 \\
\%\end{array}$ & 4.11 \\
\hline $\begin{array}{l}\text { Kegiatan pelatihan kerudung ini mampu } \\
\text { menambah keterampilan }\end{array}$ & $.0 \%$ & $.0 \%$ & $\begin{array}{c}22.2 \\
\%\end{array}$ & $11.1 \%$ & $\begin{array}{c}66.7 \\
\%\end{array}$ & 4.44 \\
\hline Kegiatan pelatihan ini mudah dilakukan & $.0 \%$ & $\begin{array}{c}11.1 \\
\%\end{array}$ & $\begin{array}{c}27.8 \\
\%\end{array}$ & $38.9 \%$ & $\begin{array}{c}22.2 \\
\%\end{array}$ & 3.72 \\
\hline $\begin{array}{l}\text { Teknik pembuatan nugget mudah diingat } \\
\text { sehingga saya mampu melakukan sendiri }\end{array}$ & $.0 \%$ & $5.6 \%$ & 27.8 & $38.9 \%$ & 27.8 & 3.89 \\
\hline
\end{tabular}




\begin{tabular}{|l|c|c|c|c|c|c|}
\hline pasca pelatihan & & & $\%$ & & $\%$ & \\
\hline $\begin{array}{l}\text { Setelah kegiatan pelatihan pembuatan nugget } \\
\text { ini, saya berniat untuk berwirausaha dengan } \\
\text { membuat berbagai macam variasi nugget }\end{array}$ & $11.1 \%$ & $5.6 \%$ & $\begin{array}{c}11.1 \\
\%\end{array}$ & $33.3 \%$ & 38.9 & 3.83 \\
$\%$ & & & $\%$ \\
\hline
\end{tabular}

\section{KESIMPULAN}

Berdasarkan hasil kegiatan pelatihan tersebut dapat disimpulkan bahwa:

1. Sebagian besar peserta berpendapat bahwa kegiatan ketrampilan pembuatan nugget tahu dan nugget tempe pada akhirnya mampu menumbuhkan intensi mereka untuk berwirausaha karena proses kegiatan pembuatan nugget tahu dan nugget tempe ini mudah diingat dan mudah dilakukan sehingga setelah kegiatan pelatihan ini berakhir peserta mampu membuat produk itu sendiri dan bersedia menjual produk itu sebagai usaha dalam menumbuhkan jiwa wirausaha.

2. Sebagian besar peserta merespon kegiatan pelatihan pembuatan nugget tahu dan nugget tempe ini dengan baik. Mereka merasa senang dan nyaman selama mengikuti kegiatan pelatihan. Mereka juga mampu mengikuti setiap arahan dari pemateri dan mampu menjawab pertanyaan dengan baik. Mereka sangat antusias mengikuti kegiatan pelatihan ini mulai dari awal hingga akhir pelatihan, hal ini dikarenakan sangat jarang mereka mendapatkan kegiatan dalam bentuk praktek yang dapat menambah ketrampilan dan melatih kemandirian melalui pelatihan.

\section{SARAN}

1. Perlu diadakan pelatihan lanjutan tentang bagaimana cara membuka usaha bisnis di bidang frozen food dan bagaimana cara memasarkannya. Pelatihan lanjutan ini akan sangat membantu para peserta yang berkeinginan untuk membuka usaha bisnis sendiri.

2. Perlunya kerjasama secara intensif antara pemerintah, institusi/yayasan, dan lembaga swadaya masyarakat untuk membentuk kelompok-kelompok tertentu yang akan menyadarkan dan memberi bekal pengetahuan bagaimana seharusnya membina dan memberdayakan para remaja .

3. Perlu dilaksanakan program kegiatan alternatif lainnya selain kegiatan pelatihan pembuatan nugget ini mengingat pengurus panti asuhan sangat terbuka apabila ada pelatihan-pelatihan selanjutnya.

\section{DAFTAR RUJUKAN}

Departemen Pendidikan Nasional. (2004). Pedoman Pelatihan dan Modul Pendidikan Kecakapan Hidup (Life Skills Education) Bagi Fasilitator Pendidik Sebaya di Sekolah Menengah Pertama dan Sederajat), Jakarta.

Departemen Sosial RI. (1999). Pedoman Perlindungan Anak. Jakarta : DirektoratBina Kesejahteraan Anak, Keluarga dan Lanjut Usia \& Direktorat JenderalBina Kesejahteraan Sosial Departemen Sosial RI.

Fardiati Ari, Purwana Dedi. (2011). Menjadi Wirausaha Sukses. Bandung.:PT. Remaja Rosadakarya

Marzuki, Saleh. (2010). Pendidikan Non Formal Dimensi Dalam Keaksaraan Fungsional, Pelatihan dan Andragogi. Bandung : Remaja Rosdakarya 
Muchti. (2000). Pandangan Umum Mengenai Penyesuaian Diri dan Kesehatan Mental serta Teori-teori Terkait. [on-line]. http://library.gunadarma.ac.id/go.php?id=jiptumm-gdl-sl-2003.

Sholeh, Gerry. (2014). Panti Asuhan Mahbubiyah. Surabaya

Saidi Wahyu,Sofia Hartati. (2008). Kewirausahaan. Jakarta:Enno Media

Saiman, Leonardus. (2009). Kewirausahaan. Jakarta. Salemba Empat

Santoso, Harianto. (2005). Disini Matahariku Terbit. Jakarta: PT Gramedia 